\title{
TEKNIK GURU BERTANYA PADA PEMBELAJARAN BAHASA INDONESIA SISWA KELAS XI RPL 3 SMK NEGERI TUGUMULYO
}

\author{
Dian Ramadan Lazuardi ${ }^{1}$, Ari Priyanto ${ }^{2}$ \\ Program Studi Pendidikan Bahasa dan Sastra Indonesia, STKIP-PGRI Lubuklinggau ${ }^{1,2}$ \\ dianramadan78@gmail.com ${ }^{1}$
}

Submit, 15-11-2017 Accepted,31-12-2017 Publish,31-12-2017

\begin{abstract}
ABSTRAK
Penelitian ini bertujuan untuk menganalisis keterampilan guru bertanya dalam pembelajaran Bahasa Indonesia siswa kelas XI RPL 3 SMK Negeri Tugumulyo. Metode penelitian yang digunakan adalah metode deskriptif kualitatif. Lokasi penelitian ini di SMK Negeri Tugumulyo Kelas XI RPL. Data dalam penelitian ini yaitu hasil pencatatan atau rekaman. Sumber data utama dalam penelitian ini ialah kata-kata dan tindakan. Teknik analisis data penelitian yaitu transkripsi data, reduksi data, display data, verifikasi, dan menarik kesimpulan.Hasil penelitian menunjukkan bahwa keterampilan bertanya guru pada proses pembelajaran Bahasa Indonesia siswa kelas XI RPL 3 SMK Negeri Tugumulyo baik. Hal ini terlihat dari kedua aspek penilaian keterampilan bertanya, guru memenuhi semua aspek keterampilan bertanya tingkat dasar dan tingkat lanjut yang berjumlah 60 pertanyaan.
\end{abstract}

Kata Kunci: Bertanya, Dasar, dan Lanjut.

\section{ABSTRACT}

This Research aim to analyse skill enquire by Indonesian XI RPL class student subject teacher 3 SMK NegeriTugumulyo. Used by method research is descriptive method qualitative. this research location in SMK NegeriTugumulyo Class XI RPL. Data in this research that is result of record or record-keeping. Source of especial data in this research isaction and words. Technique analyse research data that is data transkripsi, data discount, displayed by data, verification, and conclude. Result of research indicate that skill enquire teacher at process study of Indonesian XI RPL class student good SMK NegeriTugumulyo. This matter seen from both aspect assessment of skill enquire, teacher fulfill all skill aspect enquire advanced and elementary storey level which amount to 60 question.

Keyword: Enquiring, Base, and Continue.

\section{PENDAHULUAN}

Memberi pertanyaan kepada siswa merupakan kegiatan yang tidak dapat dipisahkan dalam kegiatan proses belajar mengajar. Salah satu ciri kompetensi proses belajar mengajar bagi seorang guru ialah keterampilan mengajar dan membangkitkan siswa berpikir kreatif. Keterampilan itu didukung oleh kemampuan seorang guru 
mengajukan pertanyaan yang terprogram kepada siswa, sehingga terciptlah suasana belajar yang kondusif. Menurut Imron (2000), suasana belajar yang kondusif adalah suasana yang mendukung bagi terciptanya kegiatan belajar yaitu suasana yang interaktif, dimana para siswa aktif belajar di dalamnya, tentu tidak sebatas ketika ditunggui oleh guru. Pada saat guru sedang tidak menunggui, maka siswa tetap aktif dan giat belajar.

Guru yang profesional harus menguasai keterampilandasarmengajar, antara lain keterampilanbertanya. Dari awal pembelajaran, inti sampai menutup pelajaran guru seringmemberikanpertanyaankepadasiswa.Menurut Nasution (2002), pertanyaan adalah stimulus yang membimbing anak untuk berpikir dan belajar. Dari proses pertanyaan yang diajukan oleh guru kepada siswa, hal itu dapat menjadi pembuka jalan kearah belajar yang baik untuk mencapai tujuan yang diharapkan bersama.

Terjadinya proses belajar mengajar di kelas dengan memberi pertanyaan kepada siswa agar berpengaruh positif tidaklah mudah. Kebanyakan guru dalam memberi pertanyaan kepada siswa bukan membuat siswa mengerti, melainkan merasa bingung dengan pertanyaan guru itu sendiri. Pertanyaan kadangkala diberikan tidak sesuai dengan taraf kematangan siswa atau tidak sesuai dengan topik yang sedang dibahas, sehingga siswa merasa bosan dan malas belajar. Sebelum seorang guru mengajukan pertanyaan atau mempersiapkan pertanyaan, sebaiknya seorang guru harus mendalami pokok bahasan pembelajaran, memperhatikan pengetahuan yang telah dimiliki oleh siswa, memperhatikan lingkungan keluarga, dan situasi kelas.Sebagaimana yang dikemukakan Joni (2003), bahwa dalam proses belajar mengajar setiap pertanyaan, baik itu berupa kalimat tanya atau kalimat suruh yang menuntut respon siswa, sehingga siswa dapat memperoleh pengetahuan dan meningkatkan kemampuan berpikir. Selain dari itu, siswa dapat terlatih mengemukakan pendapat dan gagasannya dengan mengembangkan keempat keterampilan berbahasa salah satunya, yaitu membaca.

Jadi, sebagai seorang guru kita dapat memperhatikan hal-hal yang perlu diperhatikan dalam memberi pertanyaan yang diajukan dengan menggunakan teknik bertanya guru yang efektif dan efisien untuk menimbulkan perubahan tingkah laku dan respon siwa terhadap topik yang dibahas, sehingga proses belajar mengajar akan berhasil sesuai yang diharapkan. 
Dalam proses pembelajaran berlangsung akan timbul bermacam-macam jenis pertanyaan yang akan diajukan guru.Sering kali guru memberikan pertanyaan pada siswa untuk mengetahui seberapa jauh pengetahuan siswa tentang pelajaran yang telah atau sedang diajarkan. Tidak jarang pula guru mendapatkan jawaban yang diinginkan atau respon balik dari siswa. Guru akan berfikir kenapa siswa diam, dan ada dua kemungkinan,siswa diam karena tidak bias menjawab atau diam karena tidak bias menerima materi pelajaran yang telah diberikan. Padahal, bertanya adalah bentuk nyatadari proses berpikir itusendiri sebab pada umumnya guru menggunakan tanyajawab sebagai komunikasi dalam proses pembelajarannya.

Tujuan dari penelitian ini adalah untuk mendeskripsikan teknik bertanya dasar guru dalam proses pembelajaran Bahasa Indonesia dan mendeskripsikan teknik bertanya lanjut guru dalam proses pembelajaran Bahasa Indonesia. Penelitian ini juga dapat berguna untuk penelitian tentang teknik bertanya guru dengan membangkitkan respon siswa dalam proses pembelajaran yang sedang berlangsung, memberikan masukan yang positif bagi perkembangan penelitian di dalam bidang teori pengajaran bahasa Indonesia, dapat menambah informasi bagi guru bidang studi bahasa Indonesia, memberikan arahan bagi guru bidang studi bahasa Indonesia untuk menciptakan pengajaran yang lebih akrab, melibatkan siswa secara aktif untuk merespon pertanyaan yang diajukan dalam proses pembelajaran yang sedang berlangsung.

\section{METODE PENELITIAN}

Metode dalam penelitian ini adalah metode dekriptif kualitatif. Menurut Moleong (2006), metodologi kualitatif sebagai prosedur penelitian yang menghasilkan data deskriptif berupa kata-kata tertulis atau lisan dari orang-orang dan perilaku yang dapat diamati. Lokasi penelitian ini di SMK NegeriTugumulyoKelas XI RPL.Menurut Arikunto (2006) data adalah hasil pencatatan penelitian, baik yang berupa fakta ataupun angka. Data dalam penelitian ini yaitu hasil pencatatan atau rekaman tentang teknik bertanya guru dan respon siswa dalam pembelajaran Bahasa Indonesia.Sumber data utama dalam penelitian ini ialah kata-kata dan tindakan selebihnya adalah data tambahan seperti dokumentasi dan lain-lain.

Instrumen penelitian yang dimaksudkan dalam penelitian ini adalah peneliti sebagai alat penelitian utama agar dapat memutuskan secara luwes dan senantiasa 
menilai keadaan, serta dapat mengambil keputusan sendiri. Penelitian yang akan dilakukan observasi, tes, rekaman, dan wawancara. Instrumen pendukung dalam penelitian ini adalah tape recorder atau alatperekam lainnya.

Teknik yang digunakan untuk mengumpulkan data dalam penelitian ini, adalah obsevasi penelitian digunakan untuk melihat secara langsung situasi pengajaran yang menggunakan teknik bertanya guru dan respon siswa terhadap pertanyaan. Selanjutnya rekaman terhadap kata-kata ujaran atau kata-kata lisan guru dan siswa selama proses pembelajaran bahasa Indonesia berlansung. Teknik rekaman ini dilakukan secara bersama-sama saat observasi di kelas. Kemudian wawancara dilakukan kepada guru bahasa Indonesia yang mengajar di SMK NegeriTugumulyoKelas XI RPL.Dari data yang dikumpul langkah selanjutnya yaitu transkripsi data, reduksi data, display data, verifikasi, dan menarik kesimpulan.

\section{HASIL PENELITIAN}

Teknik bertanya dasar dan bertanya lanjut guru di kelas XI RPL 3 SMK Negeri Tugumulyo pada proses pembelajaran Bahasa Indonesia berjumlah 60 pertanyaan yang bervariasi. Rincian teknik bertanya dasar dan bertanya lanjut guru dapat dilihat pada tabel berikut ini:

Tabel 1

Teknik Bertanya Dasar dan Bertanya Lanjut

\begin{tabular}{clc}
\hline \multicolumn{1}{l}{ Teknik Bertanya Dasar } & \multicolumn{1}{c}{ Teknik Bertanya } & Jumlah \\
\hline No & \multicolumn{1}{c}{ Pengungkapan Pertanyaan secara Jelas dan Singkat } & 14 \\
\hline 1. & Pemberian acuan & 7 \\
\hline 2. & Pemusatan & 3 \\
\hline 4. & Pemindahan giliran & 2 \\
\hline 5. & Penyebaran & 1 \\
\hline 6. & Pemberian waktu berfikir & 8 \\
\hline 7. & Pemberian tuntunan & 5 \\
\hline Teknik Bertanya Lanjut & 9 \\
\hline 1. & Pengubahan tuntutan tingkat kognitif & 5 \\
\hline 2. & Pengaturan urutan pertanyaan & 3 \\
\hline 3. & Penggunaan pertanyaan pelacak & 3 \\
\hline 4. & Peningkatan terjadinya interaksi & $\mathbf{6 0}$ \\
\hline Total & & \\
\hline & & \\
\hline
\end{tabular}


Berdasarkan data di atas peneliti menguraikan beberapa hal yaitu keterampilan guru dalam bertanya pada dasarnya sudah baik. Guru mengungkapkan pertanyaan secara jelas dan singkat, guru juga memberian acuan, tuntunan, waktu berfikir, dan pemindahan giliran yang bertujuan untuk memudahkan siswa menjawab pertanyaanpertanyaan.

Keterampilan guru dalam bertanya dasar dalam proses pembelajaran dilihat dari kemampuan guru pada saat menyampaikan materi pelajaran di dalam kelas. Pada saat proses pembelajaran berlangsung guru sering memberikan pertanyaan kepada siswa, dan siswa berusaha menjawab pertanyaan yang guru berikan. Sehingga terlihat suasana belajar yang aktif, semangat, dan menarik.

Selanjutnya pada keterampilan bertanya tingkat lanjut merupakan lanjutan dari keterampilan bertanya dasar dan berfungsi untuk mengembangkan kemampuan berfikir siswa dan mendorong mereka agar dapat mengambil inisiatif sendiri. Komponen keterampilan bertanya tingkat lanjut yang diberikan guru kepada siswa yaitu, pengubahan tuntunan tingkat kognisi dalam menjawab pertanyaan, pertanyaan yang dikemukakan oleh guru dapat mengandung proses mental yang berbeda-beda dari proses mental yang rendah sampai proses mental yang tinggi. oleh karena itu, dalam mengajukan pertanyaan, guru berusaha mengubah tuntunan tingkat kognisi dalam menjawab pertanyaan dari tingkat yang paling rendah, yaitu evaluasi ingatan, pemahaman, penerapan, analisis dan sintesis. Pengaturan urutan pertanyaan, untuk mengembangkan tingkat kognisi dari yang sifatnya lebih rendah kearah lebih tinggi dan kompleks, guru dapat mengatur urutan pertanyaan yang diajukan kepada siswa. penggunaan pertanyaan pelacak, jika jawaban yang diberikan oleh siswa dinilai benar oleh guru, tetapi masih dapat ditingkatkan menjadi sempurna, guru dapat mengajukan pertanyaan-pertanyaan pelacak kepada siswa tersebut.

Peningkatan terjadinya interaksi, agar siswa lebih terlihat secara pribadi dan lebih bertanggung jawab atas kemajuan dan hasil diskusi, guru mengurangi atau menghilangkan peranan sebagai penanya sentral dengan cara mencegah pertanyaan dijawab oleh seorang siswa. dan jika siswa mengajukan pertanyaan, guru tidak segera menjawab, tetapi melontarkan kembali kepada siswa lainnya. 


\section{PEMBAHASAN}

\section{Pengungkapan Pertanyaan Secara Jelas dan Singkat}

Pertanyaan yang diungkapkan seorang guru harus jelas, singkat, dan menggunakan kata-kata yang dapat dipahami oleh siswa. berikut adalah pembahasan tentang pengungkapan pertanyaan secara jelas dan singkat:

"Apa petunjuk?"

"Terus petunjuk, apa petunjuk?”

Data di atas menunjukkan bahwa pertanyaan yang diungkapkan oleh guru kepada siswanya jelas dan singkat. Hal ini terlihat dari kata tanya yang digunakan yaitu apa yang mengarah pada jawaban singkat pula. Dalam proses pembelajaran juga terlihat sebagian besar siswa mampu menjawab pertanyaan yang diberikan oleh guru dan sama sekali tidak merasa kesulitan ketika mendengar pertanyaan tersebut.

\section{Pemberian Acuan}

Pemberian acuan yaitu sebelum guru mengajukan pertanyaan, guru perlu memberikan acuan pertanyaan yang berisi informasi yang relevan dengan jawaban yang diharapkan dalam diri siswa. berikut adalah pembahasan tentang pemberian acuan:

"Perintah adalah suruhan. Makanya buatlah kalimat perintah. Kelas X sudah belajar. Kalimat perintah tentunya apa saja, perintah permintaan, perintah permohonan. Itu merupakan kalimat perintah. Harus kalian pahami disini. Adakan secara lisan. Iya secara lisan disampaikan perintah dari atasan ke?"

Kutipan percakapan tersebut menunjukkan bahwa guru memberikan acuan terhadap pertanyaan berupa informasi-informasi yang relevan mengenai kalimat perintah. Guru membantu siswa mengingat materi yang telah dipelajari sebelumnya. Hal ini dapat membantu siswa mengolah informasi untuk menemukan jawaban yang benar dan membuat kalimat perintah sesuai dengan jenisnya.

\section{Penyebaran}

Melibatkan siswa sebanyak-banyaknya dalam proses pembelajaran guru perlu menyebarkan giliran menjawab pertanyaan secara acak, yaitu berusaha agar siswa mendapatkan giliran secara merata dengan pertanyaan yang berbeda kepada siswa yang berbeda pula. 
"Perintah ya, tentang surat perintah yang harus dilaksanakan dan terus ada satu surat ada kaki suratnya apa saja Oci?"

Kutipan percakapan tersebut menunjukkan bahwa guru melibatkan siswa secara bergiliran dalam proses pembelajaran, guru memberikan giliran kepada siswa untuk menjawab pertanyaan secara acak mengenai surat perintah.

\section{Pemberian Waktu Berfikir}

Pemberian waktu berfikir yaitu setelah mengajukan pertanyaan kepada siswa, guru memberikan waktu beberapa detik untuk siswa berpikir sebelum menunjukkan salah seorang siswa untuk menjawab, agar siswa dapat menemukan dan menyusun jawaban dengan baik dan benar. Seperti pada kutipan percakapan-percakapan di bawah ini:

"Perintah kerja tertulis sudah disampaikan. Apo sih perintah. Perintah adalah, Dera? Perintah adalah, ayo siapa yang bisa?" (006)

Kutipan percakapan tersebut menunjukkan bahwa setelah memberikan pertanyaan guru memberikan waktu beberapa detik kepada siswa untuk berpikir, kemudian menunjuk siswanya untuk menjawab pertanyaan.

\section{Pemberian Tuntunan}

Bila seorang siswa tidak mampu memberikan jawaban yang benar guru hendaknya memberikan tuntunan kepada siswa, sehingga siswa dapat menemukan sendiri jawaban yang benar. Seperti pada kutipan percakapan-percakapan di bawah ini:

"Bahasa Indonesia kadang-kadang rancu lho. Pegangan itu apa (sambil memperagakan memegang) sama pegang beda ya. Di sini harus kalian pahami, di sini ada jenis perintah kerja tertulis ada lima. Imbauan (sambil menunjuk jenis yang pertama), apa yang bisa kita lihat?”

Kutipan percakapan tersebut menunjukkan bahwa guru memberikan tuntunan kepada siswanya dengan memperhatikan langsung jenis perintah kerja tertulis yang ada dalam buku pegangan guru dan siswa. 


\section{Pengubahan Tuntunan Tingkat Kognitif}

Seorang guru dalam mengajukan pertanyaan, dapat merubah tuntunan tingkat kognitif yang sekedar mengingat, tetapi dapat pula ke tingkat kognitif yang lebih tinggi. Seperti pada kutipan percakapan di bawah ini:

“Terus petunjuk, apa petunjuk?

"Cara penggunaan suatu barang."

"Penggunaan suatu barang, contohnya apa?"

Pertanyaan yang diajukan oleh guru pada kutipan di atas menunjukan bahwa guru memberikan pertanyaan dengan tingkatan dari yang rendah ke tingkat yang makin tinggi.

\section{Pengaturan Urutan Pertanyaan}

Seorang guru dapat mengatur urutan bertanya yang diajukan kepada siswa secara baik. Mula-mulanya, seorang guru mengajukan pertanyaan pemahaman, setelah itu pertanyaan penerapan, analisis, sintesis, dan akhirnya pertanyaan evaluasi. Seperti pada kutipan percakapan di bawah ini:

"Inget lho nanti di akhir ada lho tugasnya. Apa sih bedanya peraturan? Terus contohnya, di mana letaknya? Terus ada pedoman, pedoman sama peraturan hampir mirip kakak beradik 11-12 bedanya di mana? Apa contohnya coba?"

Kutipan pertanyaan tersebut menunjukkan bahwa guru mengurutkan pertanyaan dari yang mudah ke tingkat yang sulit. Hal ini bertujuan untuk membantu siswa menjawab pertanyaan dengan mudah dan sistematis.

\section{Penggunaan Pertanyaan Pelacak}

Berikut ini salah satu kutipan pertanyaan pelacak yang diberikan oleh guru di dalam proses pembelajaran:

"Manifestasi, ayo siapa yang bisa. Awas lho kata-kata baru di dalam kamus Bahasa Indonesia, manifestasi apa? Apo sih bedanya manifestasi dengan investasi, investasi apa?"

Pada kutipan di atas menunjukkan bahwa guru malacak beberapa kata untuk memudahkan siswa mengingat sebuah informasi, seningga siswa mampu menjawab pertanyaan dengan benar. 


\section{SIMPULAN}

Berdasarkan hasil penelitian yang telah peneliti lakukan, maka dapat ditarik kesimpulan bahwa keterampilan bertanya guru pada proses pembelajaran Bahasa Indonesia siswa kelas XI RPL 3 SMK Negeri Tugumulyo sudah baik. Hal ini terlihat saat guru melaksanakan kegiatan belajar mengajar telah memenuhi semua aspek keterampilan bertanya dasar dan bertanya lanjut yang berjumlah 60 pertanyaan.

\section{DAFTAR PUSTAKA}

Arikunto, Suharsimi. (2006). Prosedur Penelitian Suatu Pendekatan Praktik. Jakarta: PT Asdi Mahasatya.

Imron, Ali. (2000). Belajar dan Pembelajaran. Jakarta: PT DuniaPustaka.

Joni, T. Raka. (2003). Keterampilan Bertanya dan Lanjut Panduan Pengajaran Mikro 1. Jakarta: Departemen dan Kebudayaan.

Meleong, Lexy J. (2006). Metodologi Penelitian Kualitatif. Bandung: PT Remaja Rosdakarya.

Nasution. (2002). Didaktik Asa-asas Mengajar. Bandung: Jemmars. 